\title{
Plasminogen activator production and enhanced development in medium containing plasminogen or plasmin by rabbit embryos in vitro
}

\author{
M. A. Grobner and A. R. Menino, Jr* \\ Department of Animal Sciences, Oregon State University, Corvallis, OR 97331-6702, USA
}

\begin{abstract}
A series of experiments was conducted to evaluate plasminogen activator production and effects of supplementing culture medium with plasminogen or plasmin on development of rabbit embryos in vitro. In Expt 1, 495 one- to two-cell embryos were cultured in Ham's F-12 with $15 \mathrm{mg} \mathrm{BSA} \mathrm{ml}^{-1}$ containing $0,30,60$ or $120 \mu \mathrm{g}$ porcine plasminogen $\mathrm{ml}^{-1}$ or $0,75,150$ or $300 \mu \mathrm{g}$ rabbit plasminogen $\mathrm{ml}^{-1}$. Percentages of embryos developing to the expanded blastocyst, hatching blastocyst and hatched blastocyst stages were greater $(P<0.05)$ in medium with $120 \mu \mathrm{g}$ porcine plasminogen $\mathrm{ml}^{-1}$ than in the absence of plasminogen. More $(P<0.05)$ embryos developed to the blastocyst, expanded blastocyst and hatching blastocyst stages in medium with $300 \mu \mathrm{g}$ rabbit plasminogen $\mathrm{ml}^{-1}$ than in the absence of plasminogen. In Expt 2, 216 one- to two-cell embryos were cultured in medium with $0,30,60$ or $120 \mu \mathrm{g}$ porcine plasminogen $\mathrm{ml}^{-1}$ for $96 \mathrm{~h}$, fixed and stained with haematoxylin and eosin, and the number of cells determined. No differences $(P>0.05)$ were observed in number of cells of morulae but blastocysts developing in medium with $120 \mu \mathrm{g}$ porcine plasminogen $\mathrm{ml}^{-1}$ had more $(P<0.05)$ cells $(109.9 \pm 10.4)$ than did blastocysts in medium with either $0(69.4 \pm 14.6)$ or $30 \mu \mathrm{g}$ porcine plasminogen $\mathrm{ml}^{-1}(73.3 \pm 12.2)$. In Expt 3, 144 one- to two-cell embryos were cultured in medium with 0,13 or $45 \mu \mathrm{g}$ porcine plasmin $\mathrm{ml}^{-1}$ or $120 \mu \mathrm{g}$ porcine plasminogen $\mathrm{ml}^{-1}$. Development to the hatched blastocyst stage was greater $(P<0.05)$ in medium with $45 \mu \mathrm{g}$ porcine plasmin $\mathrm{ml}^{-1}$ or $120 \mu \mathrm{g}$ porcine plasminogen $\mathrm{ml}^{-1}$ than in medium with 0 or $13 \mu \mathrm{g}$ porcine plasmin $\mathrm{ml}^{-1}$. In Expt 4, 101 embryos at days 3, 4 and 5 after mating were cultured to equivalent gestational age day 7, and medium was recovered at intervals of $24 \mathrm{~h}$ and assayed for plasminogen activator. Production of plasminogen activator was greater $(P<0.05)$ on days 6 and 7 than on days 4 and 5 for embryos collected on day 3 , and was greater $(P<0.05)$ on day 7 than on day 6 for embryos collected on day 5. Although production of plasminogen activator progressively increased, no differences $(P>0.05)$ were observed by day in culture for embryos collected on day 4 . These results suggest that rabbit embryos produce plasminogen activator during the peri-implantation period, and respond to plasmin and plasminogen in the culture medium with improved development.
\end{abstract}

\section{Introduction}

Several investigators have reported on the divergent morphology and biochemical characteristics of rabbit embryos developing in vitro compared with embryos developing in vivo (Maurer and Beier, 1976; Fischer, 1987; Hegele-Hartung et al., 1988; Jung and Fischer, 1988; Fischer $e$ t al., 1992). The retarded development in vitro can be ameliorated to a limited extent by including uterine flushings in the culture medium or it can be restored to normal development in vivo by transfer to pseudopregnant recipients (Fischer, 1987; Hegele-Hartung et al., 1988; Jung and Fischer, 1988; Fischer et al., 1990, 1992). One series of processes affected by culture in vitro are the changes in the extracellular embryonic coverings that occur

*Reprint requests.

Revised manuscript received 11 January 1994. before implantation. Rabbit embryos possess extracellular embryonic coverings that undergo a dynamic remodelling process (Boving, 1963; Denker and Gerdes, 1979). Zygotes are initially surrounded by a zona pellucida to which a mucoprotein layer (mucolemma) is added during oviductal transport (Boving, 1963). After uterine entry and development to the blastocyst stage, the zona pellucida becomes indiscernible, and a new layer, the neozona, is formed. The neozona immediately surrounds the embryo and is composed of material of both trophoblastic and maternal origin (Denker and Gerdes, 1979). By day 6 after coitus, a mucous layer of uterine origin, the gloiolemma, is added to the neozona and mucolemma (Boving, 1963). Fischer $e$ t al. (1991) demonstrated that uterine components are required for dissolution of the zona pellucida and that formation of the neozona does not occur during development in vitro. 
Remodelling of these extracellular embryonic coverings is considered to be important in the initiation of implantation (Denker and Hafez, 1975; Denker, 1977) and to be mediated by proteases from the uterus or blastocyst (Kirchner, 1972; Denker, 1974; Denker and Hafez, 1975; Denker, 1977; Denker and Gerdes, 1979). Complete identities of the proteases involved in the restructuring of the extracellular embryonic coverings in the rabbit are not known. Denker (1977) identified a trypsin-like serine protease, referred to as blastolemmase, that may participate in dissolution of the coverings at the blastocyst stage. Denker (1977) observed little proteolytic activity in blastocysts up to day 6 after coitus; however, blastolemmase activity increased dramatically in the trophoblast and extracellular embryonic coverings of blastocysts from day 6.5 to day 7 after coitus. Blastolemmase may be either directly synthesized by the trophoblast or synthesized by the endometrium as a proenzyme and subsequently activated by the trophoblast (Denker, 1977).

Embryos from several species including mice (Strickland et al., 1976), pigs (Mullins et al., 1980), cattle (Menino and Williams, 1987) and sheep (Menino et al., 1989) produce the serine protease plasminogen activator. Plasminogen activator production has been implicated in trophoblastic penetration of the endometrium (Strickland et al., 1976; Sappino et al., 1989), metabolism of Reichert's membrane by parietal endoderm (Strickland et al., 1976; Strickland, 1980), facilitation of hatching (Menino and Williams, 1987; Menino et al., 1989) and tissue remodelling during changes in blastocyst shape (Fazleabas et al., 1983). When plasminogen or plasmin is included in the culture medium, hatching or shedding of the zona pellucida is accelerated or increased in cattle and sheep embryos, respectively (Menino and Williams, 1987; Menino et al., 1989), and hatching, attachment and trophoblastic outgrowth are enhanced in mouse embryos (Menino and O'Claray, 1986). Plasminogen is a uterine constituent (Fazleabas et al., 1983; Finlay et al., 1983) and would be available to the embryo as a source of protease for tissue remodelling or restructuring of extracellular embryonic coverings. Neither production of plasminogen activator nor the effects of the plasminogen-plasmin system on development in vitro, with the exception of a report by Kane (1986) with plasmin, have been investigated in early rabbit embryos. The objectives of this research were therefore to evaluate the effects of plasminogen and plasmin on development in vitro and to identify production of plasminogen activator by rabbit embryos.

\section{Materials and Methods}

\section{Embryo collection and culture}

New Zealand White rabbit does were superovulated by one of two methods. The first method was s.c. injections of $0.5 \mathrm{mg}$ pig FSH (Sigma Chemical Company, St Louis, MO) twice daily for 3 days. The second method was a single s.c. injection of 150 iu of pregnant mares' serum gonadotrophin (PMSG; Calbiochem-Behring Corporation, San Diego, CA). Ninety-six hours after either the initial porcine $\mathrm{FSH}$ injection or single PMSG injection, does were naturally mated and injected i.p. with 100 iu hCG (Sigma Chemical Company). Embryos were surgically collected from does $1,3,4$ and 5 days after mating. For embryo collection, does were anaesthetized by injecting i.m. $60 \mathrm{mg}$ ketamine hydrochloride (Vetalar: Park-Davis, Morris Plains, NJ) and $10 \mathrm{mg}$ xylazine (Rompum: Haver, Shawnee, KS) $\mathrm{kg}^{-1}$ body mass. A ventral midline laparotomy was performed and the reproductive tract was exteriorized. Collection of embryos on days 1 and 3 (day 0: day of mating) was accomplished by retrograde flushing of the oviduct through a catheter inserted in the infundibulum. Collection of embryos on days 4 and 5 was accomplished by inserting a catheter proximal to the cervix of each uterine horn and flushing the uterus from the utero-tubal junction. Each individual oviduct or uterine horn was flushed with 5 and $10 \mathrm{ml}$, respectively, of Ham's F-12 (Sigma Chemical Company) buffered with $25 \mathrm{mmol}$ Hepes $\mathrm{l}^{-1}$ (Sigma Chemical Company). Flushings were examined using a dissecting microscope, and embryos exhibiting normal morphology for their respective age were collected from the flushings by aspiration.

Embryos were washed once in Hepes-buffered Ham's F-12 supplemented with $15 \mathrm{mg} \mathrm{BSA} \mathrm{ml}^{-1}$ (Sigma Chemical Company), placed into screw-cap test tubes maintained at $37^{\circ} \mathrm{C}$ and transported to the laboratory for culture. Embryos were washed three times and cultured in $50 \mu \mathrm{l}$ Ham's F-12 with $15 \mathrm{mg} \mathrm{BSA} \mathrm{ml}{ }^{-1}$ under paraffin oil (Fisher Scientific Company, Tustin, $\mathrm{CA}$ ) at $37^{\circ} \mathrm{C}$ in a humidified atmosphere of $5 \% \mathrm{CO}_{2}$ in air. Four to ten embryos, depending on the developmental age at collection, were cultured in each microdrop; culture duration varied from 48 to $192 \mathrm{~h}$. Each microdrop within a treatment was considered as a replicate. The morphology of embryos was evaluated at intervals of $24 \mathrm{~h}$ at $\times 100-200$ using an invertedstage phase-contrast microscope, and stage of development was recorded. Where appropriate after evaluation embryos were transferred to fresh medium, and medium was recovered and stored at $-20^{\circ} \mathrm{C}$ until assayed for plasminogen activator activity. Medium containing no embryos and incubated under identical conditions was collected to correct for spontaneous activation of plasminogen and to detect plasmin contamination in plasminogen-containing medium.

\section{Experiment 1: development of rabbit embryos in medium containing plasminogen}

The objectives of this experiment were to evaluate the effects of plasminogen on the development of one- to two-cell embryos to the morula and blastocyst stages, and to determine whether embryos produced plasminogen activator and activated plasminogen to plasmin. Three hundred one- to two-cell embryos (Fig. 1) were cultured in microdrops of Ham's F-12 with $15 \mathrm{mg} \mathrm{BSA} \mathrm{ml}^{-1}$ containing $0(n=82), 30(n=70), 60$ $(n=69)$ or $120 \quad(n=79) \mu g$ porcine plasminogen (Sigma Chemical Company) $\mathrm{ml}^{-1}$ for $192 \mathrm{~h}$; each treatment comprised 14 replicates. These concentrations were selected because they approximate to physiological values (Fazleabas et al., 1983; Finlay et al., 1983) and developmental effects with porcine plasminogen have been demonstrated in cultured mouse (Menino and O'Claray, 1986), cattle (Menino and Williams, 1987) and sheep (Menino et al., 1989) embryos. At intervals of $24 \mathrm{~h}$, morphology of embryos was assessed and they were transferred to fresh microdrops. Medium was collected and 


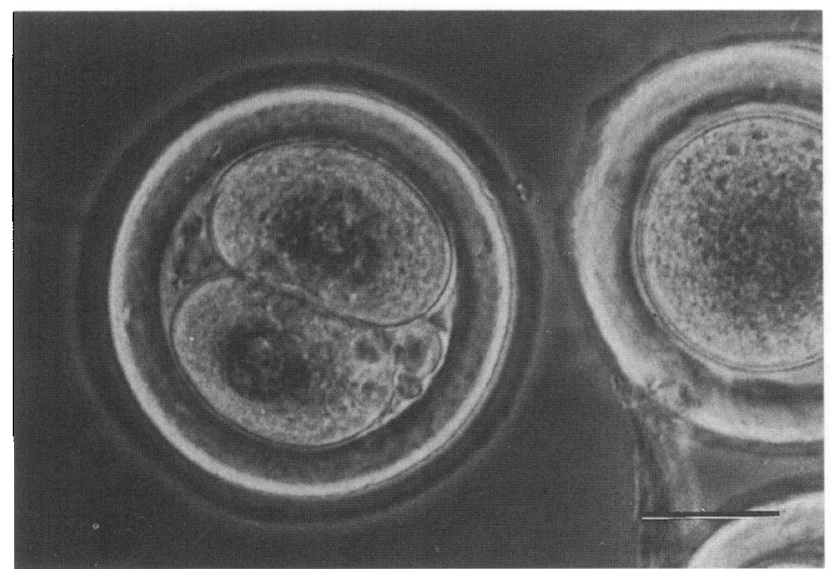

Fig. 1 One- to two-cell rabbit embryos collected $24 \mathrm{~h}$ after mating. (Scale bar represents $50 \mu \mathrm{m}$.)

stored at $-20^{\circ} \mathrm{C}$ until assayed for plasminogen activator and plasmin activities. To determine whether the effects observed with heterologous plasminogen were physiological, a second group of embryos was cultured in medium containing homologous plasminogen. One hundred and ninety-five one- to two-cell embryos were cultured in microdrops of Ham's F-12 with $15 \mathrm{mg} \mathrm{BSA} \mathrm{ml}^{-1}$ containing $0(n=40), 75(n=40), 150$ $(n=39)$ or $300(n=40) \mu \mathrm{g}$ rabbit plasminogen (Sigma Chemical Company) $\mathrm{ml}^{-1}$ or $60 \mu \mathrm{g}$ porcine plasminogen $\mathrm{ml}^{-1}$ $(n=36)$ for $168 \mathrm{~h}$; each treatment comprised four replicates. Concentrations of rabbit plasminogen were selected on the basis of plasmin activities assayed for porcine plasminogen. At $24 \mathrm{~h}$ intervals, the morphology of the embryos was assessed and they were transferred to fresh microdrops. Medium was recovered and stored at $-20^{\circ} \mathrm{C}$ until assayed for plasminogen activator and plasmin activities.

\section{Experiment 2: numbers of cells of rabbit embryos cultured in} medium containing plasminogen

The objective of Expt 2 was to evaluate a potential mitogenic effect of plasminogen on cultured rabbit embryos. Two hundred and sixteen one- to two-cell embryos were cultured in Ham's F-12 with $15 \mathrm{mg} \mathrm{BSA} \mathrm{ml}{ }^{-1}$ containing 0 $(n=53), 30(n=54), 60(n=54)$ or $120(n=55) \mu \mathrm{g}$ porcine plasminogen $\mathrm{ml}^{-1}$ for $96 \mathrm{~h}$; each treatment contained eight replicates. The morphology of the embryos was assessed at intervals of $24 \mathrm{~h}$. At the end of culture, embryos were recovered from the microdrops, washed twice in $2.0 \%$ sodium citrate, transferred to $0.7 \%$ sodium citrate for $3 \mathrm{~min}$, fixed onto microscope slides with $25 \%$ acetic acid in ethanol, air-dried (McGaughey and Chang, 1969) and stained with haematoxylin and eosin to determine the number of cells.

\section{Experiment 3: development of rabbit embryos in medium containing plasmin or plasminogen}

The principal objective of this experiment was to determine whether the improved development observed in medium with porcine plasminogen was due to the plasmin contaminant

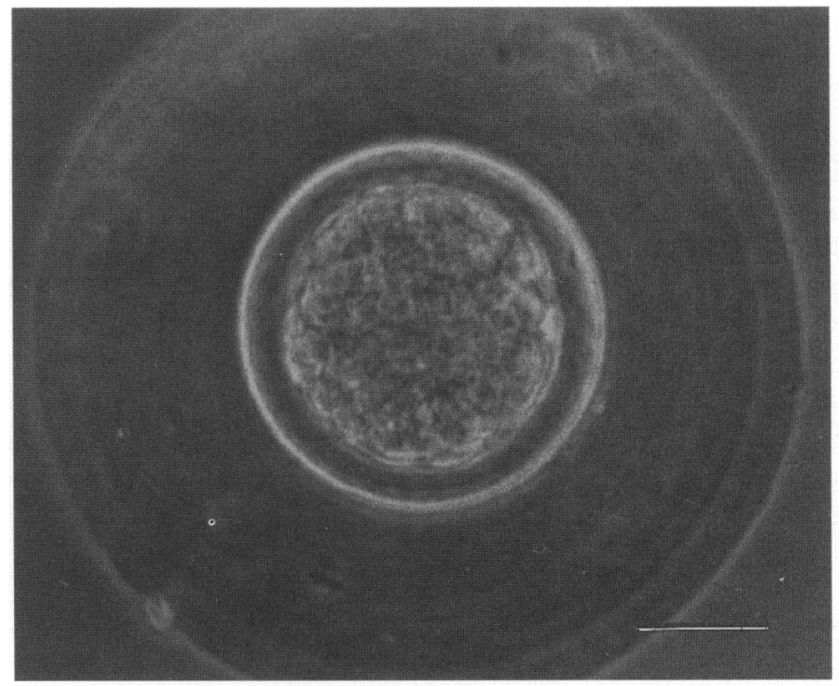

Fig. 2. Rabbit morula collected $72 \mathrm{~h}$ after mating. (Scale bar represents $50 \mu \mathrm{m}$.)

accompanying it and whether such development could be supported by a similar amount of plasmin. A secondary objective was to evaluate the effects of plasminogen and plasmin on the rates of development to a particular cell stage. One hundred and forty-four one- to two-cell embryos were cultured in Ham's F-12 with $15 \mathrm{mg} \mathrm{BSA} \mathrm{ml}{ }^{-1}$ containing 0 $(n=39)$ or $120(n=31) \mu \mathrm{g}$ porcine plasminogen $\mathrm{ml}^{-1}$ and 13 $(n=37)$ or $45(n=37) \mu \mathrm{g}$ porcine plasmin $\mathrm{ml}^{-1}$ for $168 \mathrm{~h}$; each treatment was composed of seven replicates. Plasmin concentrations were chosen to represent the amounts of plasmin contaminant assayed and total plasmin that could be activated in $120 \mu \mathrm{g}$ porcine plasminogen $\mathrm{ml}^{-1}$ (13 and $45 \mu \mathrm{g}$ plasmin $\mathrm{ml}^{-1}$, respectively). The morphology of the embryos was assessed at intervals of $24 \mathrm{~h}$.

Experiment 4: production of plasminogen activator by rabbit embryos on days 3,4 and 5

The objective of Expt 4 was to identify plasminogen activator production by rabbit embryos collected as morulae and blastocysts and cultured to the equivalent of gestational age day 7 . One hundred and one rabbit embryos were collected on days $3(n=37), 4(n=24)$ and $5(n=40)$ after mating and cultured in Ham's F-12 with $15 \mathrm{mg} \mathrm{BSA} \mathrm{ml}^{-1}$ (Fig. 2 ); each day was represented by $4-8$ replicates. Embryos collected on days 3,4 and 5 were cultured for 96,72 and $48 \mathrm{~h}$, respectively. At intervals of $24 \mathrm{~h}$, the morphology of the embryos was assessed and they were transferred to fresh microdrops. Medium was recovered and stored at $-20^{\circ} \mathrm{C}$ until assayed for plasminogen activator activity.

\section{Plasminogen activator and plasmin assays}

Plasminogen activator and plasmin activities were measured in culture medium using a casein-agar gel assay, as described by Menino and Williams (1987) and Kaaekuahiwi and Menino (1990) for cattle embryos. Briefly, activities of plasminogen 
Table 1. Development of one- to two-cell rabbit embryos in Ham's F-12 containing 0, 30, 60 or $120 \mu \mathrm{g}$ porcine plasminogen $\mathrm{ml}^{-1}$

\begin{tabular}{|c|c|c|c|c|c|c|}
\hline \multirow[b]{2}{*}{$\begin{array}{l}\text { Plasminogen } \\
\left(\mu \mathrm{gl}^{-\mathrm{I}}\right)\end{array}$} & \multirow[b]{2}{*}{$\begin{array}{l}\text { Number of } \\
\text { embryos }\end{array}$} & \multicolumn{5}{|c|}{ Number $(\%)$ of embryos at developmental stage } \\
\hline & & Morula & Blastocyst & $\begin{array}{l}\text { Expanded } \\
\text { blastocyst }\end{array}$ & $\begin{array}{l}\text { Hatching } \\
\text { blastocyst }\end{array}$ & $\begin{array}{l}\text { Hatched } \\
\text { blastocyst }\end{array}$ \\
\hline 0 & 82 & $65(79)^{a}$ & $19(23)^{\mathbf{a}}$ & $3(4)^{\mathrm{a}}$ & $1(I)^{a}$ & $0(0)^{a}$ \\
\hline 30 & 70 & $53(76)^{a}$ & $25(36)^{a}$ & $9(13)^{\mathrm{b}}$ & $2(3)^{\mathbf{a}}$ & $0(0)^{\mathrm{a}}$ \\
\hline 60 & 69 & $54(78)^{\mathrm{a}}$ & $25(36)^{\mathbf{a}}$ & $18(26)^{\mathrm{c}}$ & $9(13)^{b}$ & $3(4)^{\mathrm{ab}}$ \\
\hline 120 & 79 & $63(80)^{a}$ & $22(28)^{a}$ & $19(24)^{\mathrm{bc}}$ & $9(11)^{b}$ & $6(8)^{b}$ \\
\hline
\end{tabular}

${ }^{\text {ab }}$ Numbers in the same column with different superscripts are significantly different $(P<0.05)$.

Calculated chi-squared values for development to the morula, blastocyst, expanded blastocyst, hatching blastocyst and hatched blastocyst stages with three degrees of freedom are $0.44,4.32,18.54,12.27$ and 10.86, respectively.

activator were determined with urokinase (E.C.3.4.21.31; Sigma Chemical Company) as the standard in concentrations of 0 , $0.001,0.005,0.01,0.05$ and $0.10 \mathrm{mU} \mathrm{ml}^{-1}$. Medium or urokinase standards $(15 \mu \mathrm{l})$ were incubated with $15 \mu \mathrm{l}$ of $120 \mu \mathrm{g}$ human plasminogen $\mathrm{ml}^{-1}$ (Sigma Chemical Company) at $37^{\circ} \mathrm{C}$ for $15 \mathrm{~min}$. Aliquots of the incubated mixture $(25 \mu \mathrm{l})$ were placed into wells $4 \mathrm{~mm}$ in diameter cut in an agar gel plate containing $1 \%$ nonfat dry milk (Carnation Company, Los Angeles, CA) and $1 \%$ agarose (Sigma Chemical Company) and incubated for $24 \mathrm{~h}$ at room temperature. At the end of incubation, plates were fixed for 10 min with $3 \%$ acetic acid, rinsed with tap water and the diameters of the caseinolytic zones were measured using a vernier calliper. Plasminogen activator concentrations in the medium were determined from the equation of the line calculated for the caseinolytic diameters by $\log$ urokinase concentrations. The quantity of plasminogen activator produced by the embryo $\left(\mathrm{PA}_{\mathrm{E}}\right)$ was determined by deducting the amount in the medium without any embryos from the amount in the medium with an embryo for each $24 \mathrm{~h}$ interval. Plasminogen activator production $\left(\mathrm{mU} \times 10^{-4} \mathrm{ml}^{-1}\right)$ per day per viable embryo was calculated by dividing $P A_{E}$ by the number of viable embryos observed at each $24 \mathrm{~h}$ interval.

Plasmin and nonspecific protease activities in the culture medium were determined with porcine plasmin (E.C.3.4.21.7; Sigma Chemical Company) as the standard in concentrations of $0,5,10,50,100$ and $500 \mu \mathrm{g} \mathrm{ml}{ }^{-1}$. Medium or plasmin standard $(15 \mu \mathrm{l})$ were added to wells cut in the casein-agar gel plates and incubated for $64 \mathrm{~h}$ at room temperature. At the end of incubation, plates were fixed with $3 \%$ acetic acid, and diameters of the caseinolytic zones were measured using a vernier calliper. Plasmin concentrations or nonspecific protease activities in the medium were determined from the equation of the line calculated for caseinolytic ring diameters by log plasmin concentrations.

\section{Statistical analyses}

The effects of the various culture conditions on numbers (percentages) of embryos that developed to the morula, blastocyst, expanded blastocyst, hatching blastocyst and hatched blastocyst stages were determined using chi-squared procedures for tests of independence in $r \times 2$ contingency tables (Steel and Torrie, 1980). When a significant $(P<0.05)$ calculated chi-squared value resulted, $2 \times 2$ comparisons were conducted where appropriate. Differences in numbers of nuclei, times required for embryos to develop to a particular cell stage, and activities of plasminogen activator and plasmin were detected by analysis of variance and least significant differences procedures using the NCSS statistical software program (Number Cruncher Statistical System, Version 4.1, 1984, J. L. Hintze, Kaysville, UT).

\section{Results}

A total of 990 embryos was collected from 60 does, giving a mean embryo recovery of 16.5 embryos of which 956 were cultured.

\section{Experiment 1: development of rabbit embryos in medium containing plasminogen}

Numbers of rabbit embryos developing in vitro to the morula and blastocyst stages did not differ $(P>0.10)$ among the four concentrations of porcine plasminogen given (Table 1 ). More $(P<0.05)$ embryos developed to the expanded and hatching blastocyst stages in medium with $60 \mu \mathrm{g}$ porcine plasminogen $\mathrm{ml}^{-1}$ compared with 0 and $30 \mu \mathrm{g} \mathrm{ml}^{-1}$. Development to the expanded, hatching and hatched blastocyst stages was greater $(P<0.05)$ in medium with $120 \mu \mathrm{g}$ porcine plasminogen $\mathrm{ml}^{-1}$ than with $0 \mu \mathrm{g} \mathrm{ml} \mathrm{m}^{-1}$ (Fig. 3). Complete divesting of the zona pellucida was observed only for embryos cultured in either 60 or $120 \mu \mathrm{g}$ porcine plasminogen $\mathrm{ml}^{-1}$ (Fig. 4).

Development of rabbit embryos to the morula stage did not differ $(P>0.10)$ when the various concentrations of plasminogen were administered (Table 2). More $(P<0.05)$ embryos developed to the blastocyst stage in medium with $300 \mu \mathrm{g}$ rabbit plasminogen $\mathrm{ml}^{-1}$ compared with $0 \mu \mathrm{g} \mathrm{ml}^{-1}$. More $(P<0.05)$ embryos attained the expanded blastocyst stage in medium with 150 and $300 \mu \mathrm{g}$ rabbit plasminogen $\mathrm{ml}^{-1}$ compared with $0 \mu \mathrm{g} \mathrm{ml}^{-1}$. Fewer $(P<0.05)$ embryos commenced hatching in medium containing no rabbit plasminogen 


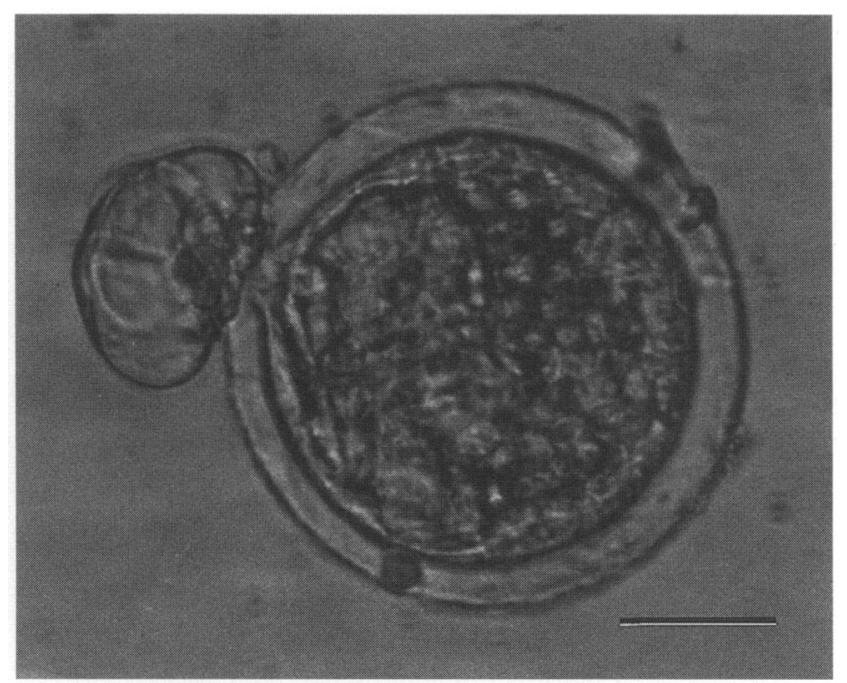

Fig. 3. Hatching blastocyst that developed from a one- to two-cell rabbit embryo after $120 \mathrm{~h}$ in Ham's F-12 containing $15 \mathrm{mg} \mathrm{BSA} \mathrm{ml}^{-1}$ and $120 \mu \mathrm{g}$ porcine plasminogen $\mathrm{ml}^{-1}$. (Scale bar represents $50 \mu \mathrm{m}$.)

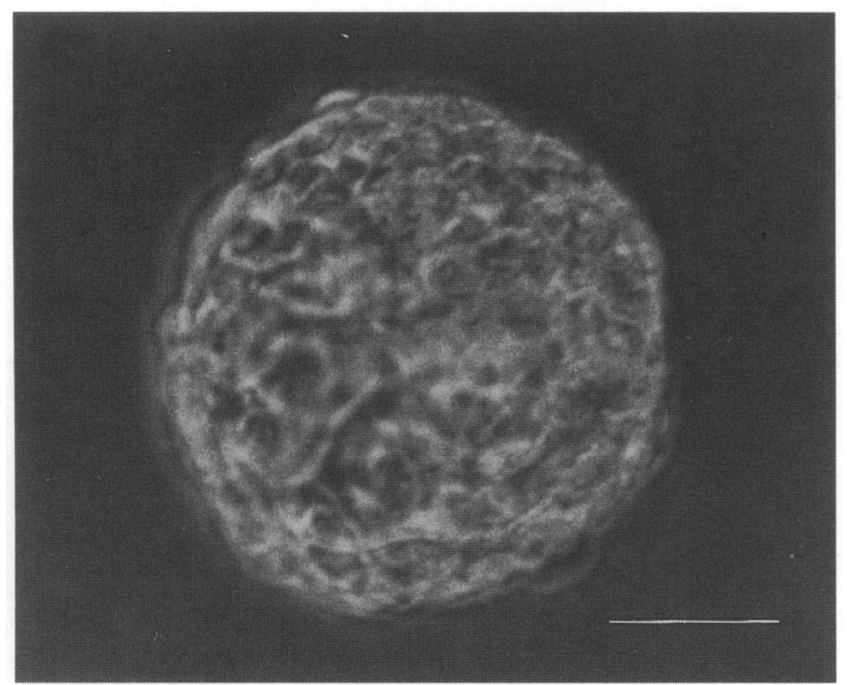

Fig. 4. Hatched blastocyst that developed from a one- to two-cell rabbit embryo after $144 \mathrm{~h}$ in Ham's F-12 containing $15 \mathrm{mg} \mathrm{BSA} \mathrm{ml}^{-1}$ and $120 \mu \mathrm{g}$ porcine plasminogen $\mathrm{ml}^{-1}$. (Scale bar represents $50 \mu \mathrm{m}$.)

than in medium containing either porcine or rabbit plasminogen, and development overall was similar $(P>0.05)$ in medium with either plasminogen. In this experiment, no embryos were observed to have completed hatching within the $168 \mathrm{~h}$ of culture.

Plasminogen activator activity and plasmin production from plasminogen were not detected in medium recovered from cultured one- to two-cell rabbit embryos (data not shown). Although some plasmin activity was detected in plasminogen-containing medium, this activity was due to an inherent plasmin contaminant and did not differ between medium recovered from embryos and control medium lacking embryos.
Experiment 2: numbers of cells of rabbit embryos cultured in medium containing plasminogen

Development to the morula, blastocyst and expanded blastocyst stages by $96 \mathrm{~h}$ of culture did not differ $(P>0.10)$ among the treatments tested and were similar to the results of Expt 1. However, the number of blastocysts hatching by $96 \mathrm{~h}$ of culture was greater $(P<0.05)$ for embryos cultured in medium containing porcine plasminogen (20 of 163), and no embryos (of 53) had initiated hatching in medium with no porcine plasminogen. At the end of the $96 \mathrm{~h}$ culture, embryos were graded for developmental stage before fixation. Numbers of cells of morulae did not differ $(P>0.10)$ with the various concentrations of porcine plasminogen administered (Table 3). However, blastocysts developing in medium with $120 \mu \mathrm{g}$ porcine plasminogen $\mathrm{ml}^{-1}$ had more cells than did blastocysts in medium with 0 or $30 \mu \mathrm{g} \mathrm{ml}^{-1}(P<0.05)$.

\section{Experiment 3: development of rabbit embryos in medium containing plasmin or plasminogen}

More $(P<0.05)$ embryos developed to the morula stage in medium with $45 \mu \mathrm{g}$ plasmin $\mathrm{ml}^{-1}$ or $120 \mu \mathrm{g}$ porcine plasminogen $\mathrm{ml}^{-1}$ compared with $13 \mu \mathrm{g}$ plasmin $\mathrm{ml}^{-1}$ (Table 4 ). However, development to the blastocyst stage was similar $(P>0.05)$ for embryos cultured in medium with 0,13 or $45 \mu \mathrm{g}$ plasmin $\mathrm{ml}^{-1}$ or $120 \mu \mathrm{g}$ porcine plasminogen $\mathrm{ml}^{-1}$. More $(P<0.05)$ embryos developed to the expanded blastocyst stage in medium with $45 \mu \mathrm{g}$ plasmin $\mathrm{ml}^{-1}$ or $120 \mu \mathrm{g}$ porcine plasminogen $\mathrm{ml}^{-1}$ than with 0 or $13 \mu \mathrm{g}$ plasmin $\mathrm{ml}^{-1}$. Onset and completion of hatching were greater $(P<0.05)$ in medium with $45 \mu \mathrm{g}$ plasmin $\mathrm{ml}^{-1}$ or $120 \mu \mathrm{g}$ porcine plasminogen $\mathrm{ml}^{-1}$ compared with medium with 0 or $13 \mu \mathrm{g}$ plasmin $\mathrm{ml}^{-1}$. Only embryos cultured in medium with $120 \mu \mathrm{g}$ porcine plasminogen $\mathrm{ml}^{-1}$ or $45 \mu \mathrm{g}$ plasmin $\mathrm{ml}^{-1}$ completed hatching. The time taken for morula formation was shorter $(P<0.05)$ for embryos cultured in medium with either porcine plasminogen or plasmin compared with medium with $0 \mu \mathrm{g}$ plasmin $\mathrm{ml}^{-1}$ (Table 5). No differences $(P>0.10)$ in developmental rates to subsequent cell stages were observed owing to plasmin or porcine plasminogen concentration in the medium.

Experiment 4: plasminogen activator production by rabbit embryos on days 3,4 and 5

Developmental stages of embryos collected on days 3,4 and 5 after mating were 16 cell to morula, morula to blastocyst and blastocyst to expanded blastocyst, respectively. Embryos from days 3 and 4 that commenced hatching by the end of culture were observed to have left the zona pellucida but remained within the confines of the mucolemma (Fig. 5). Embryos collected on day 3 exhibited little plasminogen activator activity by $48 \mathrm{~h}$ of culture but showed a tenfold increase $(P<0.05)$ by $72 \mathrm{~h}$ and a 20 -fold increase $(P<0.05)$ by $96 \mathrm{~h}$ of culture (Table 6). Plasminogen activator production for embryos collected on day 4 exhibited a similar increase over time, although no significant differences were observed. Embryos collected on day 5 demonstrated the greatest activity of plasminogen activator and exhibited a tenfold increase 
Table 2. Development of one- to two-cell rabbit embryos in Ham's F-12 containing $60 \mu \mathrm{g}$ porcine plasminogen $\mathrm{ml}^{-1}$ and $0,75,150$ or $300 \mu \mathrm{g}$ rabbit plasminogen $\mathrm{ml}^{-1}$

\begin{tabular}{|c|c|c|c|c|c|}
\hline \multirow[b]{2}{*}{$\begin{array}{l}\text { Plasminogen } \\
\left(\mu \mathrm{g} \mathrm{ml}^{-1}\right)\end{array}$} & \multirow[b]{2}{*}{$\begin{array}{l}\text { Number of } \\
\text { embryos }\end{array}$} & \multicolumn{4}{|c|}{ Number $(\%)$ of embryos at developmental stage } \\
\hline & & Morula & Blastocyst & $\begin{array}{l}\text { Expanded } \\
\text { blastocyst }\end{array}$ & $\begin{array}{l}\text { Hatching } \\
\text { blastocyst }\end{array}$ \\
\hline \multicolumn{6}{|l|}{ Porcine } \\
\hline 60 & 36 & $33(92)^{a}$ & $18(50)^{\mathrm{ab}}$ & $13(36)^{\mathrm{ab}}$ & $11(30)^{b}$ \\
\hline \multicolumn{6}{|l|}{ Rabbit } \\
\hline 0 & 40 & $35(88)^{a}$ & $11(28)^{a}$ & $10(25)^{a}$ & $4(10)^{a}$ \\
\hline 75 & 40 & $28(70)^{a}$ & $19(48)^{\mathrm{ab}}$ & $19(48)^{\mathrm{ab}}$ & $15(38)^{b}$ \\
\hline 150 & 39 & $32(82)^{\mathbf{a}}$ & $22(56)^{\mathrm{ab}}$ & $22(56)^{\mathrm{b}}$ & $16(4 I)^{b}$ \\
\hline 300 & 40 & $35(88)^{a}$ & $26(65)^{\mathrm{b}}$ & $26(65)^{b}$ & $20(50)^{b}$ \\
\hline
\end{tabular}

${ }^{a b}$ Numbers in the same column with different superscripts are significantly different $(P<0.05)$.

Calculated chi-squared values for development to the morula, blastocyst, expanded blastocyst and hatching blastocyst stages with four degrees of freedom are $8.06,12.40,16.05$ and 16.13 , respectively.

Table 3. Numbers of nuclei in rabbit morulae and blastocysts developing from one- to two-cell embryos after $96 \mathrm{~h}$ in Ham's F-12 containing $0,30,60$ or $120 \mu \mathrm{g}$ porcine plasminogen $\mathrm{ml}^{-1}$

\begin{tabular}{|c|c|c|c|c|}
\hline \multirow{2}{*}{$\begin{array}{l}\text { Plasminogen } \\
\left(\mu \mathrm{g} \mathrm{mi}{ }^{-1}\right)\end{array}$} & \multicolumn{2}{|c|}{ Morulae } & \multicolumn{2}{|c|}{ Blastocysts } \\
\hline & $n$ & Mean \pm SEM & $n$ & Mean \pm SEM \\
\hline 3 & 10 & $29.6 \pm 3.2^{a}$ & 6 & $69.4 \pm 14.6^{\mathrm{a}}$ \\
\hline 30 & 15 & $29.5 \pm 2.6^{\mathrm{a}}$ & 8 & $73.3 \pm 12.2^{\mathrm{a}}$ \\
\hline 60 & 13 & $29.3 \pm 2.8^{a}$ & 14 & $88.8 \pm 9.2^{a b}$ \\
\hline 120 & 13 & $27.3 \pm 2.8^{\mathrm{a}}$ & 11 & $109.9 \pm 10.4^{\mathrm{b}}$ \\
\hline
\end{tabular}

ab Values in the same column with different superscripts are significantly different $(P<0.05)$.

$(P<0.05)$ in production between 24 and $48 \mathrm{~h}$ of culture. Plasminogen activator production by day 5 was several times greater than that on comparable gestational days of embryos collected on days 3 or 4 (Fig. 6). Nonspecific protease activity was not observed in medium recovered from cultured rabbit embryos on days 3,4 and 5 and all caseinolytic activity was plasminogen dependent.

\section{Discussion}

The results suggest that addition of plasminogen or plasmin to culture medium for rabbit embryos at early cleavage stages improves development in vitro and that rabbit blastocysts produce plasminogen activator. The improved development was observed as accelerated development to the morula stage, increases in percentages of embryos developing to the expanded and hatching blastocyst stages, and complete escape from the zona pellucida occurring only in medium with plasminogen or plasmin. These results compare favourably with increased incidences of hatching by mouse (Menino and O'Claray, 1986) and sheep embryos (Menino et al., 1989), and accelerated development by cattle embryos (Menino and
Williams, 1987) in medium with similar concentrations of plasminogen. There are two possible explanations, which are not mutually exclusive, for the improved development in medium with plasminogen or plasmin. The effects of plasminogen or plasmin could be the result of a direct effect of the protease on the embryo, or an indirect action through weakening of the zona pellucida.

With respect to a direct effect of the protease, cell-surface receptors for both plasmin and plasminogen have been identified on human carcinoma cells (Burtin and Fondaneche, 1988) and rat glioma cells (Hall et al., 1989), and proteases have been shown to induce growth-factor-like effects on various cell types in vitro (Cunningham, 1981). Blumberg and Robbins (1975) found that some proteases, including plasmin, stimulated deoxyglucose uptake and induced cell division in chick embryo fibroblasts. Pienkowski et al. (1974) and Konwinski et al. (1978) both observed mitogenic effects of proteases on cultured mouse embryos. The increase in the number of nuclei in blastocysts developing in medium with $120 \mu \mathrm{g}$ porcine plasminogen $\mathrm{ml}^{-1}$ (albeit small and not more than twice the number in medium without protease) may be one explanation for the improved hatching observed in medium with plasminogen or plasmin. Kane (1983a) observed that hatched blastocysts had twice as many cells as did unhatched blastocysts. The increase in numbers of cells coupled with the accelerated development observed suggest that the added plasminogen or plasmin may have exerted a mitogenic effect on one- to two-cell rabbit embryos developing in vitro.

Exposure to pronase or trypsin promotes hatching by rabbit blastocysts in vitro (Onuma et al., 1968; Kane, 1983b, 1986). Kane (1986) suggested that proteases probably soften the zona pellucida by partial digestion, thereby allowing the blastocyst to grow by removing a block to expansion. Although plasminogen activator could not be detected in medium recovered from one- to two-cell embryos, it is possible that the quantity of activator produced was beyond the detection limit of the assay. Minute quantities of plasmin may have been generated that were sufficient to induce partial zonalytic effects. Although hatching does not occur in vivo in rabbits, the potential for 
Table 4. Development of one- to two-cell rabbit embryos in Ham's F-12 containing 0, 13 or $45 \mu \mathrm{g}$ porcine plasmin $\mathrm{ml}^{-1}$ or $120 \mu \mathrm{g}$ porcine plasminogen $\mathrm{ml}^{-1}$

\begin{tabular}{|c|c|c|c|c|c|c|}
\hline \multirow{2}{*}{$\begin{array}{l}\text { Plasmin/ } \\
\text { plasminogen } \\
\left(\mu \mathrm{g} \mathrm{ml}{ }^{-1}\right)\end{array}$} & \multirow[b]{2}{*}{$\begin{array}{c}\text { Number of } \\
\text { embryos }\end{array}$} & \multicolumn{5}{|c|}{ Number $(\%)$ of embryos at developmental stage } \\
\hline & & Morula & Blastocyst & $\begin{array}{l}\text { Expanded } \\
\text { blastocyst }\end{array}$ & $\begin{array}{l}\text { Hatching } \\
\text { blastocyst }\end{array}$ & $\begin{array}{l}\text { Hatched } \\
\text { blastocyst }\end{array}$ \\
\hline \multicolumn{7}{|l|}{ Plasmin } \\
\hline 0 & 39 & $26(66)^{\mathrm{ab}}$ & $13(33)^{\mathrm{a}}$ & $3(8)^{\mathrm{a}}$ & $2(5)^{\mathrm{ab}}$ & $0 \quad(0)^{a}$ \\
\hline 13 & 37 & $21(57)^{\mathrm{a}}$ & $7(19)^{\mathrm{a}}$ & $3(8)^{a}$ & $1(3)^{a}$ & $0(0)^{\mathbf{a}}$ \\
\hline 45 & 37 & $31(84)^{b}$ & $17(46)^{\mathrm{a}}$ & $12(32)^{b}$ & $12(32)^{c}$ & $10(27)^{b}$ \\
\hline \multicolumn{7}{|l|}{ Plasminogen } \\
\hline 120 & 31 & $26(84)^{b}$ & $12(39)^{\mathrm{a}}$ & $9(29)^{\mathrm{b}}$ & $6(19)^{\mathrm{bc}}$ & $4(13)^{\mathrm{b}}$ \\
\hline
\end{tabular}

${ }^{\text {ab }}$ Numbers in the same column with different superscripts are significantly different $(P<0.05)$.

Calculated chi-squared values for development to the morula, blastocyst, expanded blastocyst, hatching blastocyst and hatched

blastocyst stages with three degrees of freedom are $8.39,6.42,12.58,17.01$ and 21.22 , respectively.

Table 5. Time $(\mathrm{h})$ to the morula and blastocyst stages for oneto two-cell rabbit embryos cultured in Ham's F-12 containing 0,13 or $45 \mu \mathrm{g}$ porcine plasmin $\mathrm{ml}^{-1}$ or $120 \mu \mathrm{g}$ porcine plasminogen $\mathrm{ml}^{-1}$

\begin{tabular}{|c|c|c|c|c|}
\hline \multirow{2}{*}{$\begin{array}{l}\text { Plasmin/ } \\
\text { plasminogen } \\
\left(\mu \mathrm{g} \mathrm{ml}{ }^{-1}\right)\end{array}$} & \multicolumn{2}{|c|}{ Morula } & \multicolumn{2}{|c|}{ Blastocyst } \\
\hline & $n$ & Mean $\pm \mathrm{SE}$ & $n$ & Mean $\pm \mathrm{SE}$ \\
\hline \multicolumn{5}{|l|}{ Plasmin } \\
\hline 0 & 26 & $68.3 \pm 2.6^{a}$ & 13 & $108.9 \pm 5.4^{\mathrm{a}}$ \\
\hline 13 & 21 & $59.4 \pm 2.9^{\mathrm{b}}$ & 7 & $106.3 \pm 7.4^{\mathrm{a}}$ \\
\hline 45 & 31 & $58.1 \pm 2.3^{\mathrm{b}}$ & 17 & $110.1 \pm 4.8^{\mathrm{a}}$ \\
\hline \multicolumn{5}{|l|}{ Plasminogen } \\
\hline 120 & 26 & $55.4 \pm 2.6^{\mathrm{b}}$ & 12 & $118.0 \pm 5.7^{\mathrm{a}}$ \\
\hline
\end{tabular}

${ }^{a b}$ Values in the same column with different superscripts are significantly different $(P<0.05)$.

zonalytic effects observed with embryos developing in vitro in this study suggests that these proteins may be involved in remodelling of the extracellular embryonic coverings. Despite potential mitogenic and zonalytic roles for plasminogen and plasmin in this study, no effect of plasmin on rabbit embryo development was observed in a report by Kane (1986). However, the highest concentration of plasmin $\left(25 \mu \mathrm{g} \mathrm{ml}^{-1}\right)$ used by Kane (1986), was below that $\left(45 \mu \mathrm{g} \mathrm{ml}^{-1}\right)$ producing the greatest developmental enhancement in this study. In addition, medium with $13 \mu \mathrm{g}$ plasmin $\mathrm{ml}^{-1}$ failed to support development any more than medium containing neither plasminogen nor plasmin.

Development of rabbit embryos in rabbit plasminogen confirmed that the enhanced development attributed to porcine plasminogen was physiological. All concentrations of rabbit plasminogen examined resulted in development that was as good as or better than $60 \mu \mathrm{g}$ porcine plasminogen $\mathrm{ml}^{-1}$. Rabbit embryos may respond more to a homologous rather than to a heterologous plasminogen, assuming that it is indeed plasminogen that produces the developmental enhancement.

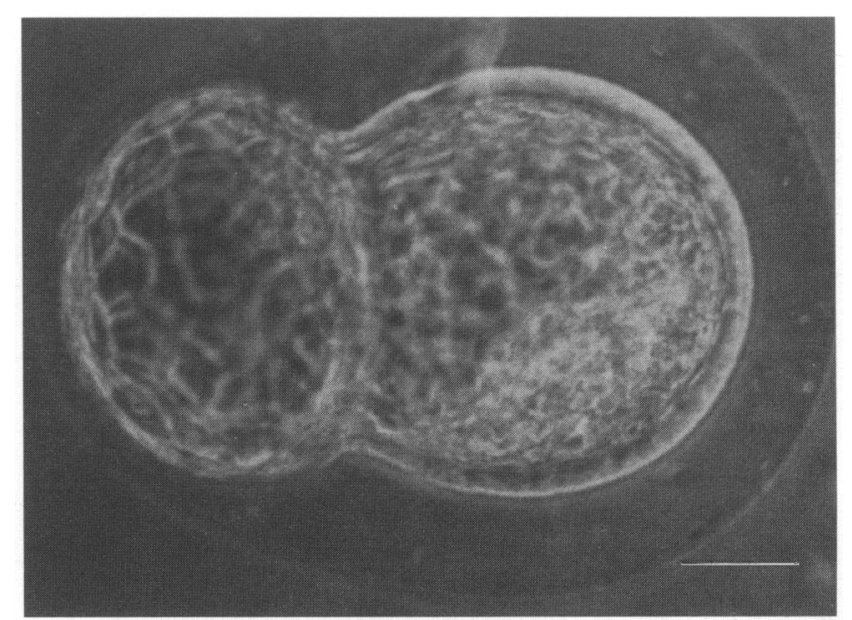

Fig. 5. Hatching blastocyst that developed from a rabbit blastocyst at day 4 after $48 \mathrm{~h}$ in Ham's F-12 containing $15 \mathrm{mg} \mathrm{BSA} \mathrm{ml}^{-1}$. (Scale bar represents $50 \mu \mathrm{m}$.)

When medium was analysed for plasminogen activator production by one- to two-cell embryos cultured for 7 or 8 days, no activity could be detected. Production of the activator was detected only by embryos collected on days 3 , 4 or 5 after mating and cultured to an equivalent gestational age of day 7. Although similar patterns of plasminogen activator production were detected for embryos collected at different equivalent gestational ages, greatest activity was observed by embryos collected on day 5 and cultured for $48 \mathrm{~h}$. Rabbit embryos developing in vitro lag behind embryos developing in vivo; this suggests that failure to detect plasminogen activator when zygotes were subjected to culture may be related to development. By ultrastructural comparison, Van Blerkom et al. (1973) found no differences between development in vivo and in vitro over the first 4 days. However, embryos cultured from the one- to two-cell stage in vitro lag behind comparably aged embryos in vivo in both number of cells and blastocyst diameter, beginning at day 3. Embryos developing in vitro do not usually have more than 500 cells (Kane, 1987). It seems evident that rabbit 
Table 6. Plasminogen activator production (milliunits $\times$ $10^{-4} \mathrm{ml}^{-1}$ per embryo) by rabbit embryos on days 3,4 and 5 after mating cultured to equivalent gestational age day 7

\begin{tabular}{lccc}
\hline & \multicolumn{3}{c}{ Day of embryo collection } \\
\cline { 2 - 4 } $\begin{array}{l}\text { Equivalent gestational } \\
\text { age (days) }\end{array}$ & 3 & 4 & 5 \\
\hline & $1.07^{\mathrm{a}}$ & - & - \\
5 & $1.28^{\mathrm{a}}$ & $5.48^{\mathrm{a}}$ & - \\
6 & $15.85^{\mathrm{b}}$ & $10.37^{\mathrm{a}}$ & $51.13^{\mathrm{a}}$ \\
7 & $25.62^{\mathrm{b}}$ & $38.69^{\mathrm{a}}$ & $544.71^{\mathrm{b}}$ \\
SEM & 4.67 & 11.91 & 133.18 \\
\hline
\end{tabular}

${ }^{a b}$ Means in the same column with different superscripts are significantly different $(P<0.05)$.

SEM: pooled standard error of the mean.

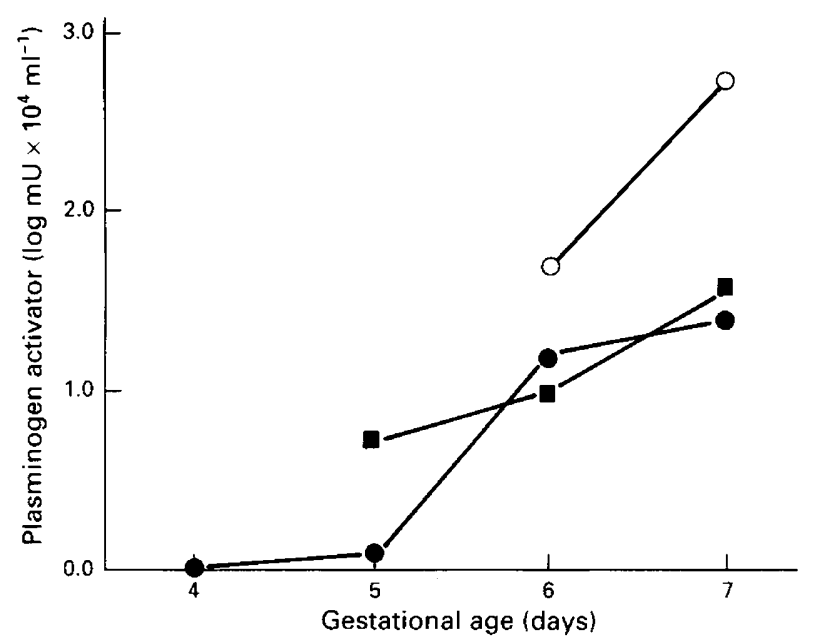

Fig. 6. Production of plasminogen activator $\left(\log \mathrm{mU} \times 10^{4} \mathrm{ml}^{-1}\right)$ by rabbit embryos collected on days $3(\bigcirc), 4(\square)$ and $5(O)$ after mating and cultured to equivalent gestational day 7 .

embryos require factors of uterine origin for normal expansion and cell division.

Jung (1989) reported a tenfold increase in protein synthesis between blastocysts developing in vivo on days 4 and 5 after mating. In fact, protein content of rabbit embryos in vivo increases from $0.2 \mu \mathrm{g}$ for day 3 morulae to $50.4 \mu \mathrm{g}$ for peri-implantation blastocysts on day 7 (Morgan and Kane, 1993). Rabbit blastocysts cultured in vitro also exhibit reduced amino acid incorporation, dependent on the duration of culture (Jung et al., 1987). Rabbit embryos that were cultured on days 3 and 4 after mating have been shown to have more dead cells and an increase in secondary lysosomes with a corresponding enhancement in protein degradation compared with embryos that were not cultured (Hegele-Hartung et al., 1988; Fischer, 1989; Fischer et al., 1992). Hegele-Hartung et al. (1988) concluded that development in vitro was slowed to a rate where a period of $24 \mathrm{~h}$ matches only a few hours of development in vivo.

In this study, embryos exposed to the day 5 uterine environment may be assumed to be more vigorous and to have the necessary mechanisms for protein production, and hence are able to produce greater quantities of plasminogen activator. Although the functional significance of the activator to the rabbit blastocyst was not elucidated in this study, several investigators have suggested a role in implantation in the mouse (Strickland ef al., 1976: Sappino et al., 1989). Sappino et al. (1989) demonstrated the presence of urokinase-type plasminogen activator mRNA in invasive and migrating trophoblast cells of mouse embryos on days 5.5 and 6.5 after mating that eventually becomes undetectable by day 10.5 . Because rabbit blastocysts increase production of plasminogen activator on day 7 , the time of implantation, it may have a similar role in facilitating endometrial penetration in rabbits.

These results suggest that addition of plasminogen or plasmin to culture medium enhances rabbit embryo development in vitro. Although the mechanism is not clear, the improved development may not necessarily depend upon proteolytic activity for induction of the mitogenic effect. The observation that rabbit blastocysts produce plasminogen activator would provide a role for plasminogen of uterine origin as a zymogen that could be activated by the embryo to provide a source of protease. This protease could help remodel the extraembryonic coverings and implantation. Similar to suggestions for mice, the finding that production of plasminogen activator was greatest by blastocysts on day 7 after mating suggests that this enzyme may be involved in implantation in rabbits.

The authors wish to thank D. Martin for typing the manuscript. Technical Paper No. 10 080, Oregon Agricultural Experiment Station.

\section{References}

Blumberg PM and Robbins PW (1975) Effect of proteases on activation of resting chick embryo fibroblasts and on cell surface proteins Cell 6 137-147 Boving BG (1963) Implantation mechanisms. In Conference on Physiological Mechanisms Concerned with Conception pp 321-396 Ed. CG Hartman. Pergamon Press, New York.

Burtin P and Fondaneche M (1988) Receptor for plasmin on human carcinoma cells Journal of the National Cancer Institute $80762-765$

Cunningham DD (1981) Proteases as growth factors. In Tissue Growth Factors pp 229-248 Ed. R. Baserga. Springer-Verlag, New York.

Denker H-W (1974) Trophoblastic factors involved in lysis of the blastocyst coverings and in implantation in the rabbit: observations on inversely oriented blastocysts Journal of Embryology and Experimental Morphology 32 739-748

Denker H-W (1977) Implantation: the role of proteases and blockage of implantation by protease inhibitors Advances in Anatomy, Embryology and Cell Biology 53 1-123

Denker H-W and Gerdes H-J (1979) The dynamic structure of rabbit blastocyst coverings. I. Transformation during regular preimplantation development Anatomy and Embryology 157 15-34

Denker H-W and Hafez ESE (1975) Proteases and implantation in the rabbit: role of trophoblast vs uterine secretion Cytobiologie 11 101-109

Fazleabas AT, Geisert RD, Bazer FW and Roberts RM (1983) Relationship between release of plasminogen activator and estrogen by blastocysts and secretion of plasmin inhibitor by uterine endometrium in the pregnant pig Biology of Reproduction 29 225-238

Finlay TH, Katz J, Kirsch L, Levitz M, Nathoo SA and Seiler S (1983) Estrogenstimulated uptake of plasminogen by the mouse uterus Endocrinology 112 856-861

Fischer B (1987) Development retardation in cultured preimplantation rabbit embryos Joumal of Reproduction and Feritity 79 115-123

Fischer B (1989) Effects of asynchrony on rabbit blastocyst development Journal of Reproduction and Fertility 86 479-491 
Fischer B, Jung T, Hegele-Hartung C and Beier HM (1990) Development of preimplantation rabbit embryos in uterine flushing-supplemented culture media Molecular Reproduction and Development 27 216-233

Fischer B, Mootz U, Denker HW, Lambertz M and Beier HM (1991) The dynamic stucture of rabbit blastocyst coverings. III. Transformation of coverings under non-physiological developmental conditions Anatomy and Embryology $183 \quad 17-27$

Fischer B, Lambertz M and Hegele-Hartung C (1992) Ultrastructural and autoradiographic study of preimplantation rabbit embryos grown in conventional or uterine flushing-supplemented culture media In Vitro Cellular and Developmental Biology 28A 337-347

Hall SW, Vandenberg SR and Gonias SL (1989) Expression of plasminogen receptors on C6 glioma cells Brain Research $495373-376$

Hegele-Hartung C, Fischer B and Beier HM (1988) Development of preimplantation rabbit embryos after in-vitro culture and embryo transfer: An electron microscopic study Anatomical Record 221 31-42

Jung T (1989) Protein synthesis and degradation in non-cultured and in vitro cultured rabbit blastocysts Joumal of Reproduction and Fertility 86 507-512

Jung T and Fischer B (1988) Correlation between blastocyst diameter and DNA or protein synthetic activity in rabbit blastocysts Biology of Reproduction 39 1111-1116

Jung T, Fischer B and Beier HM (1987) Quantitative aspects of protein synthesis in non-cultured and cultured rabbit blastocysts Human Reproduction 2 23-27

Kaaekuahiwi MA and Menino AR Jr (1990) Relationship between plasminogen activator production and bovine embryo development in vitro Journal of Animal Science 68 2009-2014

Kane MT (1983a) Variability in different lots of commercial bovine serum albumin affects cell multiplication and hatching of rabbit blastocysts in culture Joumal of Reproduction and Fertility 69 555-558

Kane MT (1983b) Evidence that protease action is not specifically involved in the hatching of rabbit blastocysts caused by commercial bovine serum albumin in culkure Joumal of Reproduction and Fertility 68 471-475

Kane MT (1986) A survey of the effects of proteases and glycosidases on culture of rabbit morulae to blastocysts Journal of Reproduction and Fertility $78 \quad 225-230$

Kane MT (1987) in vitro growth of preimplantation rabbit embryos. In The Mammalian Preimplantation Embryo: Regulation of Growth and Differentiation in Vitro pp 193-217 Ed. BD Bavister. Plenum Press, New York.

Kirchner C (1972) Uterine protease activities and lysis of the blastocyst covering in the rabbit Journal of Embryology and Experimental Morphology 28 $177-183$
Konwinski M, Solter D and Koprowski H (1978) Effect of removal of the zona pellucida on subsequent development of mouse blastocysts in vitro Journal of Reproduction and Fertility 54 137-143

McGaughey RW and Chang MC (1969) Meiosis of mouse eggs before and after sperm penetration Journal of Experimental Zoology 170 397-410

Maurer RR and Beier HM (1976) Uterine proteins and development in vitro of rabbit preimplantation embryos Joumal of Reproduction and Fertility 48 33-41

Menino AR Jr and O'Claray JL (1986) Enhancement of hatching and trophoblastic outgrowth by mouse embryos cultured in Whitten's medium containing plasmin and plasminogen Journal of Reproduction and Fertility 77 159-167

Menino AR Jr and Williams JS (1987) Activation of plasminogen by the early bovine embryo Biology of Reproduction 36 1289-1295

Menino AR Jr, Dyk AR, Gardiner CS, Grobner MA, Kaaekuahiwi MA and Williams JS (1989) The effects of plasminogen on in vitro ovine embryo development Biology of Reproduction 41 899-905

Morgan PM and Kane MT (1993) Protein content of rabbit embryos: one-cell to peri-implantation blastocyst Journal of Reproduction and Fertility 97 101-106

Mullins DE, Bazer FW and Roberts RM (1980) Secretion of a progesteroneinduced inhibitor of plasminogen activator by the porcine uterus Cell $\mathbf{2 0}$ $865-872$

Onuma H, Maurer RR and Foote RH (1968) In vitro culture of rabbit ova from early cleavage stages to the blastocyst stage Journal of Reproduction and Fertility 16 491-493

Pienkowski M, Solter D and Koprowski H (1974) Early mouse embryos: growth and differentiation in vitro Experimental Cell Research 85 285-290

Sappino AP, Huarte J, Belin D and Vassalli JD (1989) Plasminogen activators in tissue remodeling and invasion: mRNA localization in mouse ovaries and implanting embryos Joumal of Cell Biology 109 2471-2479

Steel RDG and Torrie JH (1980) Principles and Procedures of Statistics: A Biometrical Approach (2nd edn). McGraw-Hill Book Co, New York.

Strickland S (1980) Plasminogen activator in early development. In Development in Mammals pp 81-100 Ed. MH Johnson. Elsevier/North Holland Biomedical Press, New York.

Strickland S, Reich E and Sherman MI (1976) Plasminogen activator in early embryogenesis: enzyme production by trophoblast and parietal endoderm Cell 9 231-240

Van Blerkom J, Manes C and Daniel JC Jr (1973) Development of preimplantation rabbit embryos in vivo and in vitro. I. An ultrastructural comparison Developmental Biology 35 262-282 